\title{
Promoting International Procedural Norms in Competition Law Enforcement
}

\author{
Roger P. Alford ${ }^{*}$
}

INTRODUCTION

It is a pleasure to participate in the 2019 Kansas Law Review Symposium, "Antitrust Law and Policy in the 21st Century." Antitrust is once again a hot topic and discussion about how to effectively enforce the laws in a digital age is generating widespread attention. My focus will be on the topic of promoting fundamental due process in competition law investigation and enforcement. With competition authorities around the globe becoming increasingly more active, it is one of the most important topics on the antitrust agenda. And this year, we witnessed a watershed moment with the adoption of a new framework protecting due process.

The International Competition Network (ICN) unveiled the Framework on Competition Agency Procedures (CAP) in May 2019 to promote fundamental due process in competition investigation. ${ }^{1}$ As of August 2019, there were seventy-two signatories to the CAP, reflecting almost every leading competition authority. ${ }^{2}$ It was the first time in history that competition authorities from around the world entered into a multilateral framework on due process that included core due process protections and meaningful review mechanisms. It was, as United States Assistant Attorney General Makan Delrahim noted, "a remarkable and historic achievement for antitrust enforcement" that combines "strong substantive principles with meaningful review mechanisms" that "goes well beyond anything competition agencies have ever done before."3

\footnotetext{
* Professor of Law, University of Notre Dame School of Law; Former Deputy Assistant Attorney General, U.S. Department of Justice, Antitrust Division; J.D., New York University; LL.M., University of Edinburgh.

1. INT'L COMPETITION NETWORK, ICN FRAMEWORK ON COMPETITION AGENCY PROCEDURES 1 (2019), https://www.internationalcompetitionnetwork.org/wp-content/uploads/2019/04/ICN_CAP .pdf [https://perma.cc/XG9G-TJFD] [hereinafter CAP FRAMEWORK].

2. See ICN CAP Participants, INT'L COMPETITION NeTwOrK (Aug. 2019), https://www.internationalcompetitionnetwork.org/wp-content/uploads/2019/08/CAPparticipants.pdf [https://perma.cc/63NY-283J] (listing ICN CAP participants as of August 2019).

3. Press Release, U.S. Dep't of Justice, New Multilateral Framework on Procedures Approved by the International Competition Network (Apr. 5, 2019), https://www.justice.gov/opa/pr/new
} 
As discussed elsewhere, ${ }^{4}$ the CAP includes commitments with respect to fundamental due process protections, including nondiscrimination, transparency, timely notice, meaningful engagement, timely resolution, confidentiality protections, avoidance of conflicts of interest, access to information, opportunity to defend, access to counsel, attorney-client privilege, written decisions, and judicial review. ${ }^{5}$

Although not a legally binding treaty, each competition authority that is a participant to the CAP "agrees that it intends, in good faith, to adhere to th[e] Framework to the extent consistent with applicable laws." commitment is consistent with the general requirement under international law that "[e]very treaty . . . must be performed by [parties] in good faith,"7 but only to the extent that doing so comports with applicable domestic law. In essence, the CAP is a soft-law instrument that recognizes procedural norms that reflect international minimum standards.

Given the nonbinding nature of the CAP, the critical questions are, why should competition authorities comply with the CAP and how will they be held accountable for a failure to comply? This article summarizes the compliance incentives that will induce competition authorities to honor the terms of the framework. It is based on my work as Deputy Assistant Attorney General in the Antitrust Division of the Department of Justice, working directly with Assistant Attorney General Makan Delrahim and the career attorneys at the Department of Justice in negotiating the framework with dozens of other competition authorities. ${ }^{8}$

This article begins with a general discussion of why governments comply with international law norms. It then discusses the specific antitrust context in which international norms are created, the process of identifying fundamental due process norms, and the review mechanisms that were adopted to promote meaningful compliance with the CAP.

\section{COMPLIANCE WITH INTERNATIONAL NORMS}

Before addressing the specific context of the incentives for competition authorities to comply with fundamental due process norms, it merits a brief discussion of why governments generally comply with

\footnotetext{
-multilateral-framework-procedures-approved-international-competition-network [https://perma.cc /W493-BTWK].

4. Makan Delrahim \& Roger P. Alford, Promoting Fundamental Due Process in Competition Law Enforcement (2020) (unpublished manuscript) (on file with author).

5. CAP FRAMEWORK, supra note 1, at 4-7.

6. Id. at 2 .

7. Vienna Convention on the Law of Treaties art. 26, May 23, 1969, 1155 U.N.T.S. 331.

8. For a more detailed account of the negotiations of the CAP, see Delrahim \& Alford, supra note 4 .
} 
international law norms. There are a variety of responses to this question, but the short answer is that there is no one reason that government actors comply, and the incentive to comply will differ based on the context and nature of the norms.

The most obvious answer to the question of compliance is that governments respect international norms to avoid sanction, punishment, or retaliation. Examples of such coercive measures are acts of self-defense in response to an armed attack, ${ }^{9}$ collective security against the unlawful use of force, ${ }^{10}$ raising tariffs in response to trade violations, ${ }^{11}$ and foreclosing access to a market for intellectual property violations. ${ }^{12}$ The threat or use of sanctions are powerful tools to induce compliance with international norms. But such measures are only available in certain contexts where a credible threat of sanction is possible. Typically, coercion will only be applied where there is a power imbalance in the relationship among states and there is a sufficiently strong interest of more powerful states to apply coercive action to induce weaker states to comply with an international norm. ${ }^{13}$

A second reason that governments comply with international norms is to induce reciprocal behavior from other governments. One party to an international agreement may comply with obligations that confer benefits to another party with the expectation that the benefitted party will comply in a reciprocal manner. ${ }^{14}$ Reciprocity confers benefits in a variety of contexts, including diplomatic relations, ${ }^{15}$ reciprocal trade benefits, ${ }^{16}$ and the recognition of foreign judgments or arbitral awards. ${ }^{17}$ Indeed, it is a core principle of treaty observance that a "material breach of a bilateral treaty by one of the parties entitles the other to invoke the breach as a ground for terminating the treaty or suspending its operation in whole or

9. See U.N. Charter art. 51 .

10. See id. art. 42.

11. See Understanding on Rules and Procedures Governing the Settlement of Disputes art. 22 व 1, Apr. 15, 1994, Marrakesh Agreement Establishing the World Trade Organization, Annex 2, 1869 U.N.T.S. 401 (describing the circumstances under which a member may suspend concessions or other obligations).

12. See 19 U.S.C. $\S 1337(d)(2012)$

13. JACK L. GOLDSMith \& ERIC A. POSNER, THE Limits OF INTERNATIONAL LAW 28-29 (2005).

14. See generally Francesco Parisi \& Nita Ghei, The Role of Reciprocity in International Law, 36 CORNELL INT'L L.J. 93, 93-94 (2003) (discussing the importance of reciprocity in international law "because there is no overarching legal authority with compulsory jurisdiction to enforce agreements").

15. Vienna Convention on Diplomatic Relations and Optional Protocols art. 47, Apr. 18, 1961, 23 U.S.T. 3227,500 U.N.T.S. 95.

16. See, e.g., Reciprocal Trade Agreements Act of 1934, 19 U.S.C. $\S \S 1351-1354$ (2012).

17. Hilton v. Guyot, 159 U.S. 113, 227-28 (1895) (discussing the role of reciprocity in determining whether to give foreign judgments conclusive effect or to view them as "prima facie evidence only of the justice of the plaintiff's claim"); New York Convention on the Recognition and Enforcement of Foreign Arbitral Awards art. I(3), June 10, 1958, 21.3 U.S.T. 2517, 330 U.N.T.S. 4. 


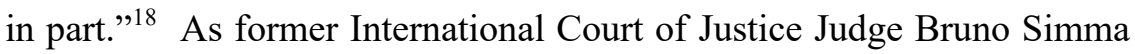
put it, "it is the reciprocal interest in the observance of certain rules ... that supplies an obvious, if not the principal, reason why international law somehow manages to accomplish its tasks, despite the absence of most institutional features considered indispensable by domestic lawyers." 19

A third reason for compliance with international norms is to promote or maintain a government's reputation. The decision to respect international norms enhances a government's reputation, while the decision to reject an international norm detracts from its reputation. ${ }^{20}$ In particular, in the multilateral context such as international organizations, where governments interact on a regular basis, there are major reputational payoffs for compliance, frequent opportunities to assess compliance, and a credible basis to anticipate likely future compliance. As Andrew Guzman has noted, "the reputational consequences of a violation will be more severe in a multilateral context-because the reputational information spreads quickly to more countries." ${ }^{21}$ The relative standing of government actors within an international network will change over time, and the desire to maintain and enhance one's standing will tend to induce norm compliance.

A fourth reason for government compliance is because the international norms already are consistent with domestic norms or are readily susceptible to becoming internalized within the domestic system. "General principles of law" are a fundamental source of international law ${ }^{22}$ which typically find their origin in domestic legal systems. ${ }^{23}$ But the reverse can also happen, with international norms becoming internalized domestically in a variety of ways, including acceptance by the broader public, adherence by political actors, or adoption by the legal system. ${ }^{24}$ Often this process of internalization is straightforward because

18. Vienna Convention on the Law of Treaties art. 60, May 23, 1969, 1155 U.N.T.S. 331.

19. 10 MPEPIL Reciprocity $\S 605$ (2012).

20. ANDREW T. GUZMAN, HOW INTERNATIONAL LAW WORKS: A RATIONAL CHOICE THEORY 73,75 (2008) ("[R] eputational payoff from compliance will be larger than the reputational payoff from violation.").

21. Id. at 72 .

22. Statute of the International Court of Justice art. 38(1)(c) ("The Court, whose function is to decide in accordance with international law such disputes as are submitted to it, shall apply ... the general principles of law recognized by civilized nations.").

23. Michelle Biddulph \& Dwight Newman, A Contextualized Account of General Principles of International Law, 26 PACE INT'L L. REV. 286, 298-99 (2014) (citing scholars such as A.D. McNair, Hersch Lauterpacht, Campbell McLachlan, and David Bederman in support of the view that "general principles of law are only those that can be identified in domestic legal systems and transposed to the international sphere").

24. See Harold Hongju Koh, The 1998 Frankel Lecture: Bringing International Law Home, 35 HOUS. L. REV. 623, 642-55 (1998) (describing the process of domestic internalization). 
international norms are broadly consistent with domestic norms and state interests, such that it is difficult to assess whether the process is one of alignment rather than internalization. ${ }^{25}$ Sometimes domestic norms, such as strong environmental protections, are exported by powerful governments onto the international plane with the hope or expectation that once they have achieved the status of international norms they will be internalized by other governments. ${ }^{26}$ These variations have a common theme of a fluid process of negotiation and dialogue between domestic norms and international norms, with each having the potential to influence the other.

Finally, a fifth reason government actors comply with an international norm is because they perceive the norm in question, and process by which it was made, to be fair and legitimate. A norm perceived to be legitimate promotes voluntary compliance by state actors, which, in the international context, is critical because of the paucity of other modes of compulsion. ${ }^{27}$ For an international norm to be perceived as legitimate pursuant to this process-based approach, there must be a community of government actors who have created a corpus of rules which the actors deem to be legitimate, and an agreed process that "legitimates the exercise of authority." 28 Government actors are more likely to voluntarily comply with an international norm if they perceive that the norm is clear and specific, ${ }^{29}$ the process of rulemaking is valid and authoritative, ${ }^{30}$ the norm is applied consistently and coherently, ${ }^{31}$ and the norm is "supported by the procedural and institutional framework within which the community [of government actors] organizes itself." 32

\section{COMPETITION ENFORCEMENT NETWORK}

Unlike other areas of law, it is not obvious how international norms are created in the antitrust context. There are no binding treaties or agreements, so the common practice of competition authorities is often the best indicator of prevailing norms. Likewise, in the antitrust context, there is no international organization similar to a treaty body that imposes rules

25. See GOLDSMITH \& POSNER, supra note 13, at 104-06.

26. See, e.g., Miranda A. Schreurs, Domestic Institutions and International Environmental Agendas in Japan and Germany, in THE INTERNATIONALIZATION OF ENVIRONMENTAL PROTECTION 134-158 (Miranda A. Schreurs \& Elizabeth C. Economy eds., 1997).

27. THOMAS M. FRANCK, FAIRNESS IN INTERNATIONAL LAW AND INSTITUTIONS 25-26 (1995).

28. Id. at 12 .

29. See id. at 30-34 (describing this indicator of legitimacy as "determinacy").

30. See id. at 34-38 (describing this indicator of legitimacy as "symbolic validation").

31. See id. at 38-41 (describing this indicator of legitimacy as "coherence").

32. Id. at 41; see id. at 42-46 (describing this indicator of legitimacy as "adherence"). 
on government enforcement behavior. ${ }^{33}$ Unlike the World Trade Organization, the United Nations Convention on the Law of the Sea, the European Convention on Human Rights, or similar treaties, there are no substantive or procedural rules of antitrust law enforcement that every Member State is obligated to respect. Nonetheless, competition law enforcers are a distinct epistemic community ${ }^{34}$ that interacts with one another on a regular basis and has established routines and practices regarding the coordination of their enforcement behavior.

The primary organizations that facilitate coordination and convergence in competition enforcement are the Organisation for Economic Co-operation and Development (OECD) Competition Committee $^{35}$ and the ICN. ${ }^{36}$ Founded in 1961, the OECD is composed of thirty-six of the leading competition authorities in the world. ${ }^{37}$ The competition authorities of OECD members meet regularly, often with authorities from nonmembers, to promote best practices in competition policy and practice. ${ }^{38}$ One of the core functions of the OECD Competition Committee is to provide a forum for government actors to articulate their position on the relevant competition issues of the day, a process that promotes best practices among other competition authorities and enhances the emergence of norms of proper behavior. ${ }^{39}$ Among the most notable achievements of the committee in recent decades is the "increase in the number of countries enforcing competition law, the convergence across jurisdictions of substantive ideas on competition law enforcement, and

33. See, e.g., Hugh M. Hollman \& William E. Kovacic, The International Competition Network: Its Past, Current and Future Role, in THE INTERNATIONAL COMPETITION NETWORK AT TEN: ORIGINS, ACCOMPLISHMENTS AND ASPIRATIONS 61 (Paul Lugard ed., 2011) (describing ICN's work product as nonbinding).

34. Peter M. Haas, Introduction: Epistemic Communities and International Policy Coordination, 46 INT'L ORG. 1, 3 (1992) (“An epistemic community is a network of professionals with recognized expertise and competence in a particular domain and an authoritative claim to policy-relevant knowledge within that domain ....").

35. International Co-operation in Competition, OECD, https://www.oecd.org/competition /internationalco-operationandcompetition.htm [https://perma.cc/V9CT-6DZD] (last visited Mar. 31, 2020).

36. About, INT'L COMPETITION NETWORK, https://www.internationalcompetitionnetwork.org /about/ [https://perma.cc/V8LY-9XQM] (last visited Mar. 31, 2020) [hereinafter About ICN].

37. History, OECD, https://www.oecd.org/about/history/\#d.en.194377 [https://perma.cc/RWV8 -RYFV] (last visited Mar. 31, 2020).

38. Best Practice Roundtables on Competition Policy, OECD, https://www.oecd.org/daf /competition/roundtables.htm [https://perma.cc/627C-PTDA] (last visited Mar. 31, 2020) [hereinafter Best Practice Roundtables]; see also Participation of UNCTAD at Best Practice Roundtables Organized by the OECD Competition Committee, U.N. CONFERENCE ON TRADE \& DEV. (Dec. 2-4, 2019), https://unctad.org/en/pages/MeetingDetails.aspx?meetingid=2336 [https://perma.cc/RPN3 -KM9V] (noting that Best Practice Roundtables are held twice a year).

39. Best Practice Roundtables, supra note 38. 
increased cooperation among competition authorities."40

The ICN was founded in 2001 as a global body devoted to providing a forum for competition authorities to address practical competition concerns. ${ }^{41}$ It has grown from 14 jurisdictions in 2001 to approximately 140 jurisdictions today. ${ }^{42}$ The "ICN's paramount goal is to facilitate convergence on superior approaches concerning the substance, procedure, and administration of competition law."43 It pursues that goal through regular annual meetings among all competition authorities that build consensus, promote best practices, and facilitate convergence on substance and procedures. ${ }^{44}$ Because the ICN is an informal network that is open for membership to all competition authorities, ${ }^{45}$ there are ample opportunities for smaller and newer agencies to host events and serve in leadership roles and enhance their reputation within the competition community of enforcers.

These two organizations provide the context for government actors to identify, promote, and enforce international norms. Applying the reasons outlined in Part I for why governments comply with international norms, one can assess the possible motivations for competition authorities to apply fundamental due process norms. The first two reasons-sanction and reciprocity - are unlikely to be factors motivating compliance. It would be highly unusual for competition authorities to face sanction or coercion as a credible means to enforce compliance with due process commitments. In addition, reciprocity is unlikely to be the reason that competition authorities comply with procedural norms. For example, the Antitrust Division of the U.S. Department of Justice will not alter its due process commitments toward parties appearing before it based on the treatment that American nationals receive by a competition authority in another country.

The ICN and the OECD do, however, promote the other three reasons for compliance with international norms. Both organizations provide ample opportunities for competition authorities to promote their reputations. These organizations provide leadership opportunities, group

40. Krisztian Katona, Interview with Frédéric Jenny, Chairman of OECD Competition Committee, ANTITRUST SOURCE, June 2018, at 1, 2.

41. About ICN, supra note 36.

42. Id.; see also Members, INT'L COMPETITION NETWORK, https://www.internationalcompetition network.org/members/ (last visited Mar. 31, 2020) [https://perma.cc/4ZKA-4R2G].

43. Hollman \& Kovacic, supra note 33, at 52.

44. Id. at 57-58 (describing ICN's method for promoting superior practice standards among members).

45. Id. at 74-75 ("Compared to its main international counterparts, ICN relies more heavily upon the contributions of [nongovernment advisors] from academia, the business community, consumer groups, and the private bar."); see also About ICN, supra note 36. 
identification, expectations of proper enforcement behavior, and articulation of substantive and procedural norms. They also typically reflect the positions of leading competition authorities, such that the norms common with those authorities often are promoted for adoption by the other competition authorities. The process of exportation by leading authorities, adoption at the international plane, and internalization elsewhere is a common phenomenon with these organizations. Finally, with both the OECD and the ICN there is an accepted process for adopting guidelines, best practices, and recommendations, enhancing the legitimacy of norms that are formalized through these organization's processes. ${ }^{46}$ To the extent the norms are promoted within the context of these organizations, the likelihood of adherence is enhanced. Thus, although these international norms promulgated by these organizations are not binding, for a variety of reasons competition authorities will tend to follow them.

In introducing the initiative on June 1, 2018, Assistant Attorney General Makan Delrahim placed special emphasis on the reputational impact of compliance. ${ }^{47}$ As Delrahim noted, "[t]he rich network of relationships ensures that reputation matters, and that the promise to abide by an obligation becomes a potent means of enhancing compliance." ${ }^{48} \mathrm{He}$ also noted that while guidelines and recommendations promulgated by international organizations are valuable, "[p]romises are different, because they create the opportunity for reflecting on decisions that may help enhance reputational standings among peers. This is true for both hardlaw commitments such as treaties, and soft-law commitments such as MOUs." ${ }^{\prime 49}$ Thus, even though the framework was nonbinding, the promise to abide by the commitments creates a reputational incentive to comply.

\section{IDENTIFYING FUNDAMENTAL DUE PROCESS NORMS}

The decision to negotiate a framework for fundamental due process raised a critical question of identifying which norms should be included as fundamental. Fortunately, a series of guidelines, best practices,

46. See, e.g., Int'L COMPetition Network, ICN ReCOMMENDED PRACTICES FOR INVESTIGATIVE PROCESS 1 (2015), https://www.internationalcompetitionnetwork.org/wp -content/uploads/2019/05/RPs-Investigative-Process.pdf [https://perma.cc/2HM6-KS7M]; ORG. FOR ECON. COOPERATION \& DEV. COMPETITION COMM., PROCEDURAL FAIRNESS AND TRANSPARENCY 5 (2012), http://www.oecd.org/daf/competition/mergers/50235955.pdf [https://perma.cc/8HU9-TTD3].

47. Makan Delrahim, Assistant Att'y Gen., U.S. Dep’t of Justice, Antitrust Div., Fresh Thinking on Procedural Fairness: A Multilateral Framework on Procedures in Antitrust Enforcement (June 1, 2018), https://www.justice.gov/opa/speech/file/1067582/download [https://perma.cc/N9HK-Z3YA].

48. Id. at 4 .

49. Id. (citations omitted). 
recommendations, and similar documents promoting procedural convergence had been adopted over the previous decade. ${ }^{50}$ By comparing the content of all of these documents one could distill a core set of norms for possible inclusion in the framework. The first draft of what became the CAP, known as the Washington Draft, was based on a survey of the work of the OECD and ICN, the competition chapters in free trade agreements, and recommendations from various bar organizations, such as the American Bar Association. ${ }^{51}$

The other way to identify fundamental due process norms was to present the Washington Draft to leading competition authorities from around the world for discussion and negotiation. This process of negotiation would start from the premise that if the leading authorities were all following certain procedural norms, then these norms were likely to be viewed as international minimum standards. In other words, actual practice by leading enforcement agencies was one of the best indicators of what fundamental due process required.

A number of agencies participated in the initial round of negotiations. These agencies were regionally diverse, representing civil and common law jurisdictions that utilized both administrative and prosecutorial systems. This group included both large and established agencies as well as smaller and younger agencies. ${ }^{52}$ The initial group of agencies that the U.S. Department of Justice invited to participate in the negotiations included the Australian Competition and Consumer Commission, Brazil's Conselho Administrativo de Defesa Econômica, the Canadian Competition Bureau, Chile's Fiscalía Nacional Económica, the Directorate-General for Competition of the European Commission, the Japan Fair Trade Commission, Mexico's Comisión Federal de Competencia Económica, New Zealand's Commerce Commission, the Competition and Consumer Commission of Singapore, the United Kingdom's Competition and Markets Authority, and the United States Federal Trade Commission. ${ }^{53}$ The second draft, known as the Paris Draft, modified the previous draft to incorporate the practices of the core group

50. See, e.g., ICN RECOMMENDED PRACTICES FOR INVESTIGATIVE Process, supra note 46, at 1; ABA Section of Antitrust LaW, InT'L TASK Force, Best Practices for Antitrust PROCEDURE 1 (2015), https://www.regeringen.se/4b013e/contentassets/fc05f4222757489ba0b7110 ae2f98144/american-bar-association-aba-section-of-antitrust-2.pdf [https://perma.cc/6XHJ-U3K3]; INT'L COMPETITION NETWORK, ICN RECOMMENDED PRACTICES FOR MERGER NOTIFICATION AND REVIEW PROCEDURES (2018), https://www.internationalcompetitionnetwork.org/wp-content/uploads /2018/09/MWG_NPRecPractices2018.pdf [https://perma.cc/XN55-MNBT]; PROCEDURAL FAIRNESS AND TRANSPARENCY, supra note 46 , at 5 .

51. Delrahim \& Alford, supra note 4, at 103-04.

52. Id. at 105 .

53. Id. 
of competition authorities. ${ }^{54}$

The third tool for identifying fundamental due process was presenting the Paris Draft to every competition authority for comment. ${ }^{55}$ The negotiations began with a core group then expanded to every interested competititon authority. This processs helped the negotiators confirm the content of fundamental due process norms and muted concerns that the negotations did not represent the full variety of experiences. Over three dozen competition authorities met in New York in September 2018, and the U.S. Department of Justice received comments from dozens of agencies. ${ }^{56}$ Thus, the third draft, known as the New York Draft, reflected the input of every interested competition authority in the world. This inclusive process gave significant credibility to the international norms that were included in the framework.

The final tool for identifying the fundamental due process norms in competition enforcement was having the ICN adopt the norms as part of its organizational process. There was significant discussion during the negotiations as to whether the framework should be implemented within the ICN rather than as a stand-alone arrangement. Most participants preferred negotiating the final draft within the ICN ${ }^{57}$ After several months of negotiation with every ICN member, in April 2019 the German Bundeskartellamt presented the final draft of the CAP to the ICN Steering Group. $^{58}$ The fact that the CAP was unanimously supported by the ICN Steering Group provided institutional credibility to the international norms, ensuring that it would secure widespread support. The CAP was opened for signature at the ICN annual meeting in Colombia in May 2019, and within the first few weeks received the support of over seventy competition authorities. ${ }^{59}$

The process that led to the adoption of the CAP reflected a growing consensus that a core set of fundamental due process norms could secure the support of competition authorities around the world. By surveying previous efforts to identify best practices, negotiating with a core group of highly respected competition authorities, opening the negotiations to every competition authority for their input, and then adopting the framework under the auspices of the ICN, the process of negotiation identified and crystallized the content of fundamental process norms in competition investigations and enforcement.

\footnotetext{
54. Id. at $105-06$.

55. Id. at 108 .

56. Id. at $108-09$.

57. Id. at 109.

58. Id. at 114 .

59. Id. at 116.
} 
The norms adopted in the framework include the following: nondiscrimination, transparency, predictability, proper notice, meaningful and timely engagement, timely resolution, confidentiality, impartiality, avoidance of conflicts of interest, opportunity to defend, access to counsel, protection of privileged information, written decisions, public access to decisions, and judicial review. ${ }^{60}$

\section{NeGOtiATING REVIEW MeCHANISMS}

Beyond identifying the content of fundamental due process norms, the other key objective was to negotiate compliance mechanisms. Without proper mechanisms to promote meaningful compliance, there were legitimate concerns that some participants to the framework may not adhere to their commitments. ${ }^{61}$ On the other hand, if the review mechanisms were too burdensome, there were genuine concerns that the framework would not receive widespread adherence. ${ }^{62}$ As with any agreement, negotiating the CAP required striking the appropriate balance between a strong agreement with few adherents and a weak agreement with many adherents. In order to improve the status quo, the framework negotiators pursued a path of a nonbinding framework that included a core set of international minimum standards, combined with meaningful review mechanisms.

International agreements frequently include provisions to promote compliance and resolve disputes. ${ }^{63}$ Those provisions fall along a continuum from soft diplomacy to binding adjudication. ${ }^{64}$ In between those extremes are a variety of review mechanisms that promote meaningful compliance without significant loss of sovereignty. ${ }^{65}$

Many treaties do not include any provision for dispute settlement beyond general commitments to negotiate or consult. ${ }^{66}$ United States extradition treaties often include such language, providing that " $[\mathrm{t}] \mathrm{he}$

60. CAP FRAMEWORK, supra note 1 , at 4-7.

61. Delrahim \& Alford, supra note 4, at 106-08.

62. Id.

63. See Kenneth W. Abbott et al., The Concept of Legalization, 54 INT'L ORG. 401, 409, 418 (2000) (discussing how rules are regarded as obligatory and how there are accepted procedures and remedies for a breach of the commitments).

64. See id. at 403, 418 ("[M] any international commitments that to a lawyer entail binding legal obligations lack significant levels of precision or delegation and are thus partial or soft under our definition.").

65. See id. at 407-08 (discussing the Montreal Protocol and noting that "the regime has developed a 'system for implementation review,' with a noncompliance procedure that still falls short of thirdparty dispute resolution but appears to have had some impact on behavior").

66. See id. at 414 ('Numerous agreements call on states to 'negotiate' or 'consult,' without specifying particular procedures.”). 
Parties may consult with each other in connection with the processing of individual cases and in furtherance of efficient implementation of this Treaty." ${ }^{, 67}$ Likewise, competition chapters in free trade agreements may include a commitment to enter into consultations regarding due process commitments. ${ }^{68}$

Other treaties address the settlement of disputes through a commitment to third-party mediation. Under the United Nations Framework Convention on Climate Change, as well as the subsequent Paris Agreement on Climate Change, the parties shall seek to resolve their disputes through negotiation, or failing that, through a conciliation commission. ${ }^{69}$ These treaties also include an optional provision for binding litigation or arbitration. ${ }^{70}$

Some treaties create a mechanism that authorizes private parties to present their case to their government agency for resolution with their counterpart agencies in other states. For example, dual taxation treaties guarantee nondiscriminatory enforcement of tax laws, and authorizes persons allegedly harmed by a violation of such a commitment to present their case to their own government's tax authority, which shall endeavor to resolve the dispute with the tax authority of the other contracting party. ${ }^{71}$

Beyond these informal mechanisms to resolve disputes and review compliance, some treaties go further and have formal monitoring and review mechanisms. Human rights treaties often take this approach. For example, the Convention on the Rights of Persons with Disabilities establishes an obligation on states to report their compliance with the

67. See, e.g., Treaty on Extradition, U.K.-U.S., art. 21, Mar. 31, 2003, T.I.A.S. No. 07-426.

68. United States - Korea Free Trade Agreement, S. Kor.-U.S., art. 16.7, June 30, 2007, https://ustr.gov/sites/default/files/uploads/Countries\%20Regions/africa/agreements/pdfs/FTAs/South \%20Korea\%20FULL.pdf [https://perma.cc/93CN-ZN7D].

69. United Nations Framework Convention on Climate Change art. 14, May 9, 1992, S. TREATY Doc. No. 102-38 (1992), 1771 U.N.T.S. 107 [hereinafter UNFCCC]; Paris Agreement to the United Nations Framework Convention on Climate Change art. 24, Dec. 13, 2015, U.N. Doc. FCCC/CP/2015/10/Add.1, annex (2016) [hereinafter Paris Agreement].

70. UNFCCC, supra note 69, art. 14; Paris Agreement, supra note 69, art. 24.

71. See, e.g., Convention Between the Government of the United States of America and the Government of the United Kingdom of Great Britain and Northern Ireland for the Avoidance of Double Taxation and the Prevention of Fiscal Evasion with Respect to Taxes on Income and on Capital Gains, U.K.-U.S., art. 26, July 24, 2001, T.I.A.S. No. 13161. The Convention describes the process of achieving dispute resolution through a government agency:

Where a person considers that the actions of one or both of the Contracting States result or will result for him in taxation not in accordance with the provisions of this Convention, he may ... present his case to the competent authority of the Contracting State of which he is a resident or national.... The competent authority shall endeavour, if the objection appears to it to be justified ... to resolve the case by mutual agreement with the competent authority of the other Contracting State, with a view to the avoidance of taxation which is not in accordance with this Convention. 
treaty and also a committee of experts to review compliance and make suggestions and recommendations based on their examination of state reports. $^{72}$ The treaty includes an optional protocol in which states may authorize the committee to receive and consider communications from individuals who claim to be victims of that state's treaty violation. ${ }^{73}$

Other agreements do not create a committee of experts; instead, they call for periodic assessment reports by treaty signatories. The Hague Adoption Convention, for example, provides that " $[t]$ he Secretary General of the Hague Conference on Private International Law shall at regular intervals convene a Special Commission in order to review the practical operation of the Convention." 74 Approximately every five years, the signatories to the Hague Adoption Convention participate in the Special Commission and approve conclusions and recommendations. ${ }^{75}$

Finally, numerous international agreements provide for binding dispute settlement. Some treaties create a private right of action that authorizes private parties to pursue arbitration against state parties alleged to have violated a due process treaty obligation. This is common in the investment treaty context. For example, the bilateral investment treaty between the United States and Argentina ${ }^{76}$ has given rise to almost two dozen cases in which United States private parties have filed investment arbitration disputes against Argentina. ${ }^{77}$ Provisions for binding dispute resolution are also common in the human rights context, and, in Europe, may protect due process guarantees in the competition law context. ${ }^{78}$

72. Convention on the Rights of Persons with Disabilities arts. 34-39, Dec. 13, 2006, 2515 U.N.T.S. 3.

73. Optional Protocol to the Convention on the Rights of Persons with Disabilities art. 1, Dec. 13, 2006, 2518 U.N.T.S. 296.

74. Convention on Protection of Children and Co-operation in Respect of Intercountry Adoption art. 42, May 29, 1993, S. TREATY DoC. NO. 105-51 (1992), 1870 U.N.T.S. 167.

75. See generally Hague Conference on Private International Law, Conclusions and Recommendations Adopted by the Fourth Meeting of the Special Commission on the Practical Operation of the 1993 Hague Intercountry Adoption Convention, at 1 (June 8-12, 2015), https://assets.hcch.net/docs/858dd0aa-125b-4063-95f9-4e9b4afd3719.pdf [https://perma.cc/YU8W -6BUR] [hereinafter Hague Special Commission Recommendations].

76. Treaty Between United States of America and the Argentine Republic Concerning the Reciprocal Encouragement and Protection of Investment, Arg.-U.S., Nov. 14, 1991, S. TREATY DOC. No. 103-2.

77. Investment Dispute Settlement Navigator, Argentina, INV. POL'Y HuB, https://investment policy.unctad.org/investment-dispute-settlement/country/8/argentina [https://perma.cc/2DSW -9HFM] (last visited Mar. 31, 2020) (listing twenty-one investment disputes United States private parties have filed against Argentina through July 31, 2019).

78. See, e.g., Convention for the Protection of Human Rights and Fundamental Freedoms art. 6, Nov. 4, 1950, E.T.S. No. 005 (providing a right to a fair trial by an impartial tribunal); see also Tamar Khuchua, Corporate Human Rights Protection in EU Competition Law Enforcement: The Standard of Protection of Companies' Rights in the Light of ECHR 19 (May 2016) (unpublished Master thesis, 
Also common are agreements that include binding dispute settlement commitments directly between the contracting parties. For example, the United States has Open Skies Agreements with over 120 countries that include provisions for consultation and binding arbitration. ${ }^{79}$ Numerous treaties confer jurisdiction on the International Court of Justice to interpret the treaty and resolve disputes between the contracting parties. ${ }^{80}$

Given the wide range of options available to promote compliance, the CAP negotiators discussed at some length which mechanisms were likely to promote compliance but not unduly encroach on sovereignty. ${ }^{81}$ At the far end of the spectrum the options of binding arbitration or litigation were rejected. $^{82}$ Given that the CAP was a nonbinding framework, it would have been inconsistent with the nature of the agreement to impose a binding dispute settlement mechanism. Establishing a commission of experts also was not on the table, because it appeared unlikely that many competition authorities would commit to such an arrangement.

From the initial draft, the Antitrust Division sought to balance the need for meaningful review with the desire to secure widespread support for the agreement; therefore, the options that the negotiators considered viable were agency self-reporting, formal and informal consultations, and periodic review mechanisms. ${ }^{83}$ These approaches had been used successfully in other treaty contexts and were likely to garner support from leading competition authorities.

As reported elsewhere, throughout the negotiations the question of review mechanisms was of central concern. ${ }^{84}$ But consistent throughout the process was the sense among many negotiators that self-reporting, consultations, and periodic assessments would facilitate compliance.

In the final version of the CAP, the self-reporting provision requires participants to publish a Template highlighting important features of their

Lund University), http://lup.lub.lu.se/luur/download?func=downloadFile\&recordOId=8894473\& file OId=8896966 [https://perma.cc/5KFX-93QM].

79. See Open Skies Partnerships: Expanding the Benefits of Freer Commercial Aviation, BUREAU ECON. \& BUS. AFFAIRS (Dec. 26, 2019), https://www.state.gov/open-skies-partnerships -expanding-the-benefits-of-freer-commercial-aviation/ [https://perma.cc/FG25-4W44] ("Since 1992, the United States has established Open Skies with over 125 foreign partners."); U.S. DEP'T OF STATE, MODEL OPEN SKIES AGREEMENT arts. 13-14 (2012), https://2009-2017.state.gov/documents /organization/114970.pdf [https://perma.cc/3Y3H-8N45].

80. See Treaties, InT'L COURT OF JUSTICE, https://www.icj-cij.org/en/treaties [https://perma.cc /NQB8-H4V2] (last visited Mar. 31, 2020) (noting that some treaties and agreements include provisions "confer[ring] jurisdiction on the Court" for issues of "application or interpretation").

81. Delrahim \& Alford, supra note 4, at 103-04.

82. Id. at 104 .

83. Id.

84. See, e.g., id. at 107-08 (describing the long process of negotiating the adherence and review mechanisms for the second draft of the framework). 
investigation and enforcement procedures that are relevant for the implementation of the framework. ${ }^{85}$ In essence, each participating competition authority is required to explain how it complies with each due process commitment, and identify any limitations that preclude compliance. As of March 2020, over half of the signatories (forty-eight out of seventy-two competition authorities) had completed templates. ${ }^{86}$

The second review mechanism is a periodic assessment of compliance by all participants to the framework. These sessions will occur at least every four years at the ICN annual conference and review the implementation and functioning of the framework, advocate for the implementation of the due process norms, and make proposals to modify the principles. ${ }^{87}$ In order to avoid the possibility of "naming and shaming," these assessments will "report on general trends, but will not identify individual Participants without consent." 88 Assuming the participants follow the Hague Adoption Convention's approach to periodic assessments, one can expect that the reports will make specific recommendations for improvements, highlight concerns regarding instances of noncompliance, and affirm progress with respect to favorable compliance trends. ${ }^{89}$ This approach avoids naming and shaming specific countries, but promotes accountability for noncompliance.

The final review mechanism used in the CAP includes a process of dialogue between the participants. Participants agree to cooperate with one another in the implementation of the framework and are free to communicate directly with each other regarding issues of compliance. ${ }^{90}$ If a participant requests a formal dialogue, it can raise any issue of competition law procedure relevant to the framework. ${ }^{91}$ The relevant participants will engage in the confidential dialogue "in good faith, according full and sympathetic consideration to the issues raised" in the dialogue. ${ }^{92}$ In essence, the CAP has incorporated a bilateral consultation process similar to what exists in competition chapters of free trade agreements, except that all such consultations shall be undertaken between

85. CAP FRAMEWORK, supra note 1 , at 3.

86. CAP Templates, INT'L COMPETITION NETWORK, https://www.internationalcompetition network.org/frameworks/competition-agency-procedures/cap-templates/ [https://perma.cc/G5VG -ZQH9] (last visited Mar. 31, 2020); ICN CAP Participants, supra note 2.

87. CAP FRAMEWORK, supra note 1, at 3; Delrahim \& Alford, supra note 4, at 116.

88. CAP FRAMEWORK, supra note 1 , at 3.

89. See generally Hague Special Commission Recommendations, supra note 75.

90. CAP FRAMEWORK, supra note 1, at 2.

91. Id. at 2-3.

92. Id. at 3 . 
competition authorities rather than trade officials. ${ }^{93}$ Such consultations have proven successful in the trade context, with the Korean Fair Trade Commission recently announcing that it would modify its procedural rules in response to concerns raised in bilateral consultations with the United States. $^{94}$

In order to ensure effective compliance, the framework creates three co-chairs to essentially serve as the secretariat or registrar of the framework. ${ }^{95}$ The inaugural co-chairs of the framework are the Australian Competition and Consumer Commission, the German Bundeskartellamt, and the United States Department of Justice, Antitrust Division. ${ }^{96}$

\section{CONCLUSION}

Promoting international procedural norms in the competition law context is still in its early stages. After over a decade of recommendations and guidelines encouraging best practices, the international competition community has finally taken a quantum leap with an agreement that obligates competition authorities to respect fundamental due process. Competition authorities are now promising one another to respect due process and submitting to a series of review mechanisms to help ensure such respect. As Assistant Attorney General Makan Delrahim recently said, "The CAP is still in its early stage, but I have been greatly encouraged by the international reception of the agreement. It has the potential to become one of the competition community's most significant achievements in promoting due process." 97

93. See, e.g., United States - Korea Free Trade Agreement, supra note 68, art. 16.7. This Free Trade Agreement provides for a bilateral consultation process:

To foster understanding between the Parties, or to address specific matters that arise under this Chapter, each Party shall, on request of the other Party, enter into consultations regarding representations made by the other Party.... The Party to which a request for consultations has been addressed shall accord full and sympathetic consideration to the concerns raised by the other Party. To facilitate discussion of the matter that is the subject of the consultations, each Party shall endeavor to provide relevant non-confidential Id. information to the other Party.

94. Wooyoung Lee \& Choi Hyung-jo, KFTC Plans to Revise Rules to Reflect Concerns with Competition Proceedings, Procedural Fairness, MLEX MARKET INSIGHT (Feb. 13, 2020, 8:05 PM).

95. CAP FRAMEWORK, supra note 1, at 2.

96. Press Release, Int'l Competition Network, Participants of the ICN Framework for Competition Agency Procedures Hold Inaugural Meeting (June 7, 2019), https://www.international competitionnetwork.org/news/icn-framework-for-competition-agency-procedures-update/ [https:// perma.cc/6KQP-J44Q].

97. Makan Delrahim, Assistant Att'y Gen., U.S. Dep’t of Justice, Antitrust Div., "With a Little Help From My Friends": Using Principles of Comity to Protect International Antitrust Achievements 13 (Sept. 12, 2019), https://www.justice.gov/opa/speech/file/1201656/download [https://perma.cc /V66T-82FY]. 